資 料 [Limnological record]

\title{
びわ湖の底層における溶存酸素飽和度と水温の連続観測
}

\author{
奥村 康昭 ${ }^{1)} \cdot$ 大西 良雄 ${ }^{1)} \cdot$ 遠藤 修-21
}

\section{Continuous measurements of dissolved oxygen and temperature in deep water of Lake Biwa}

\author{
Yasuaki OKUMURA $^{1)}$, Yoshio OHNISHI' ${ }^{1)}$ and Shuichi ENDOH ${ }^{2)}$
}

\begin{abstract}
Dissolved oxygen (DO) and temperature were measured every 30 minutes in the deep water of Lake Biwa using an oxygen data logger with a thermometer from 5 June 2000 to 3 August 2001 . The oxygen sensor of the data logger was a galvanic cell type sensor, and the thermosensor was a thermistor. The DO decreased from $60 \%$ in June and reached its minimum value of $25 \%$ in October 2000 . The maximum value of $80 \%$ was reached in January 2001 due to the overturn in winter. There was no anoxic condition during this period. The temperature increased from June to December 2000 by $0.25^{\circ} \mathrm{C}$ and then decreased by about $1.5^{\circ} \mathrm{C}$ in January 2001 due to the overturn in winter.
\end{abstract}

Key words: Lake Biwa, dissolved oxygen (DO), temperature, continuous measurements

摘 要

びわ湖北湖南部水域の北小松沖の水哚 $75 \mathrm{~m}$ 地点の湖底上約 $1 \mathrm{~m}$ に溶存酸素計を設置して, 30 分間ご との長期連続観測を実施した。観測期間は 2000 年 6 月から 2001 年 8 月の約 14 ケ月間である。溶存酸 素飽和度は観測開始直後の 6 月は約 $60 \%$ であったが，10月には約 $25 \%$ まで減少した。しかし，この 值が最低の溶存酸素飽和度でありここの観測期間中に,この地点では, 無酸素状態にはならなかった。2001 年の 1 月に鉛直循環が湖底にまで達し，溶存酸素飽和度は一挙に約 $80 \%$ まで上昇した。水温は，6月 には約 $7.2^{\circ} \mathrm{C}$ であったが，12月までの半年間で約 $0.25^{\circ} \mathrm{C}$ 上昇した。そして，1月に全層が循環した直後 に急上昇し, その後, 約 35 日間で約 $6.5^{\circ} \mathrm{C}$ まで降下して，3 月中旬から成層が始まると，また徐々に上 昇した。 キーワード : びわ湖, DO, 溶存酸素飽和度, 水温, 連続観測

(2001 年 10 月 3 日受付; 2002 年 9 月 2 日受理)

はじめに

酸素は生物の生存にとって必要不可欠である。湖沼で は, 湖水の富栄養化が進むと, 有機物を分解するために 酸素が消費され, 溶存酸素濃度が低下する。そして, 湖 底近くの酸素が無くなると, 底泥中からリンやマンガン, 硫化水素などが湖水へ溶出する(川嶋ら，1983; 前田ら，
1987)。びわ湖北湖における底層の溶存酸素は 1960 年代 の後半から年々減少し(中, 1973; 津田・森下, 1975), 部分的にではあるが無酸素状態になることも報告(熊谷, 1993)されている。

湖水の溶存酸素量を測定するには，一般的にウインク ラー法(西條・三田村，1995)が用いられるが，手間と時 間を必要とし，現場で手軽に実施できない。最近では，

1) 大阪電気通信大学工学部 = 575-0063 四條畷市清滝 1130-70. Faculty of Engineering, Osaka Electro-Communication University 113070 Kiyotaki, Shijonawate, Osaka 575-0063, Japan (E-mail:okumura@isc.osakac.ac.jp)

${ }^{21}$ 滋賀大学教育学部 T520-0862 大津市平津 2-5-1. Faculty of Education, Shiga University 2-5-1 Hiratsu, Otsu 520-0862,Japan 


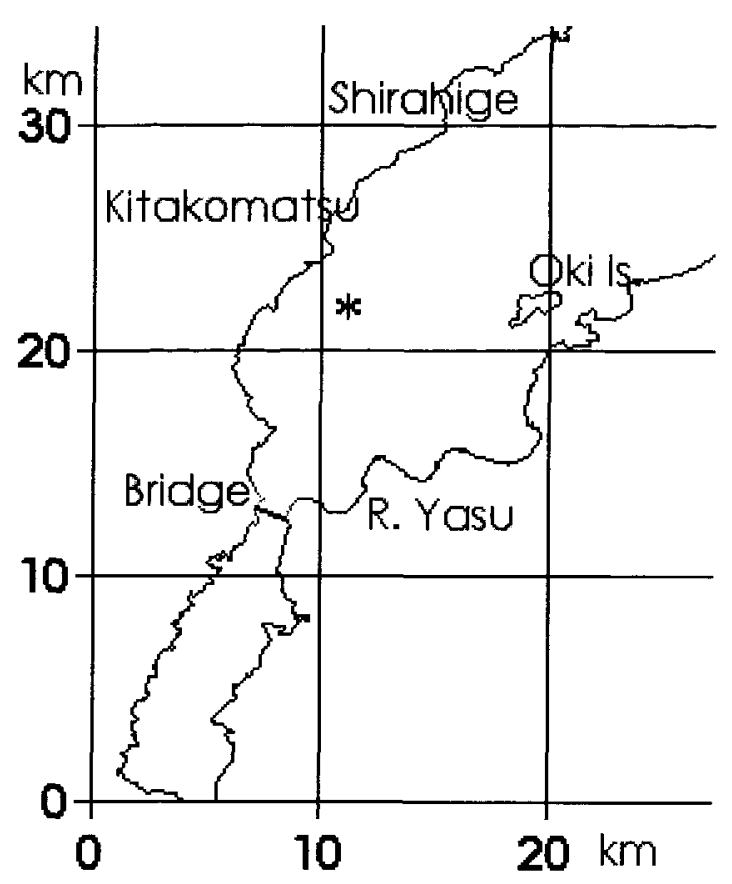

Fig. 1. Mooring site $(*)$ of the oxygen data logger in Lake Biwa.

図 1. 溶存酸素計の設置点 $(*)$.

物理的に溶存酸素量を求めるセンサーが開発され，連続 的に測定できるようになってきた。

筆者らは温度計付きの溶存酸素計をびわ湖北湖南部水 域の北小松沖約 $5 \mathrm{~km}$, 水深 $75 \mathrm{~m}$ 地点に設置して連続観 測を実施した。びわ湖水の溶存酸素濃度の観測は多数行 われているが，長期間の連続観測が行われ，まとまった データとして発表された例はない。今回の我々の観測 デー夕は年間を通じて行った最初のものである。

\section{観測地点と方法}

観測地点を Fig. 1 に*で示す。びわ湖北湖の南部西岸 北小松沖約 $5 \mathrm{~km}$ ，水深 $75 \mathrm{~m}$ の地点である。湖沼図を見 れば分かるように，びわ湖北湖は白䯿神社と沖の島を結 んだ線上が周囲より少しだけではあるが浅くなってい て，ここを境に南北に分けて考えた場合，観測地点は南 部の最深部にあたる。ここは, 我々が月に一回の観測(遠 藤ら，2001）を実施している測点に含まれ，水温の鉛直 分布のデータが得られるし, 観測時に係留線の点検も行 えるので，長期の連続観測に適している。先にも述べた ように，部分的にではあるが底層において無酸素状態が 出現することが熊谷(1993)によって報告されている。こ の地点でも, 無酸素状態が出現するのか, どうかを確認
するために連続観測を実施した。

滋賀県立衛生環境センターが，観測船による月に二回 の定期観測を実施している。この場合，周期現象に対す る分解能は一月であるし，また，無酸素状態が起こった 場合の，発生時期の確定精度は最大で 2 週間ずれること になる。定点による連綂観測は，場所的な変化をとらえ ることは出来ないが，時間的な分解能がよく，現象の発 生時期の特定に優れている。

観測に使用した溶存酸素計(メモリーDO 計，三洋測 器秼製)の大きさは，直径 $7.6 \mathrm{~cm}$, 長さ $30.5 \mathrm{~cm}$, 質量は 空中で $1.35 \mathrm{~kg}$ ，センサーにはガルバニ電池式電極を使 用している。電源には単 2 タイプのアルカリ乾電池 4 本 を直列にして使用している。中層係留法で，湖底から約 $1 \mathrm{~m}$ の高さに設置した。測定間隔は 30 分間であり,メ モリーと電源容量の関係から約 3 ケ月間の連続観測が可 能である。カタログデータによれば，測定範囲は 0 ～15 $\mathrm{mg} \mathrm{L}{ }^{-1}$, 精度は $0.05 \mathrm{mg} \mathrm{L}^{-1}$ である。サーミミタ温度計が 組み込まれていて, 温度補償された濃度值が得られるが, この論文では溶存酸素飽和度で表示する。観測期間は 2000 年 6 月 5 日 2001 年 8 月 3 日である。電池の交換 とデータの䛨み出しのために，2，3ヶ月に一回，回収 と係留を繰り返した。2001 年 4 月には持ち帰り，メー カーに依賴してセンサーの点検をしたが，感度が約 $2 \%$ 低下しているだけであった。

\section{結果と考察}

観測期間中の溶存酸素飽和度と水温のデータの時系列 変化を Fig. 2 に示す。また, Fig. 3 にはほぼ同じ期間の 水温の鉛直分布の季節变化を示してある。Fig. 3 は我々 が月に一回実施している定期観測のデータ（遠藤ら， 2001）を用いて描いたものである。

溶存酸素飽和度は 2000 年 6 月の約 $60 \%$ から 8 月の約 $40 \%$ まで，1 日当たり約 $0.3 \%$ の割合で単調に低下して いく。この期間の, みかけの酸素消費速度を求めると約 $0.03 \mathrm{mg} \mathrm{L}^{-1} \mathrm{~d}^{-1}$ となり, 熊谷ら (2001)の值に近くなる。他 の期間についても，Fig. 2 の酸素の時系列変化を見ると ほぼ同じような公配をしているので，みかけの酸素消費 速度は同じ值になると思われる。

6月から 8 月にかけて単調に減少した後，8月中旬に 少し増加する。この時期は Fig. 3 を見ても分かるように 成層が発達しているので上下の水の混合は無いので表層 から酸素が供給されたとは考えにくい。しかし，成層期 でも水平方向の水の動きは盛んであり（奥村・遠藤， 


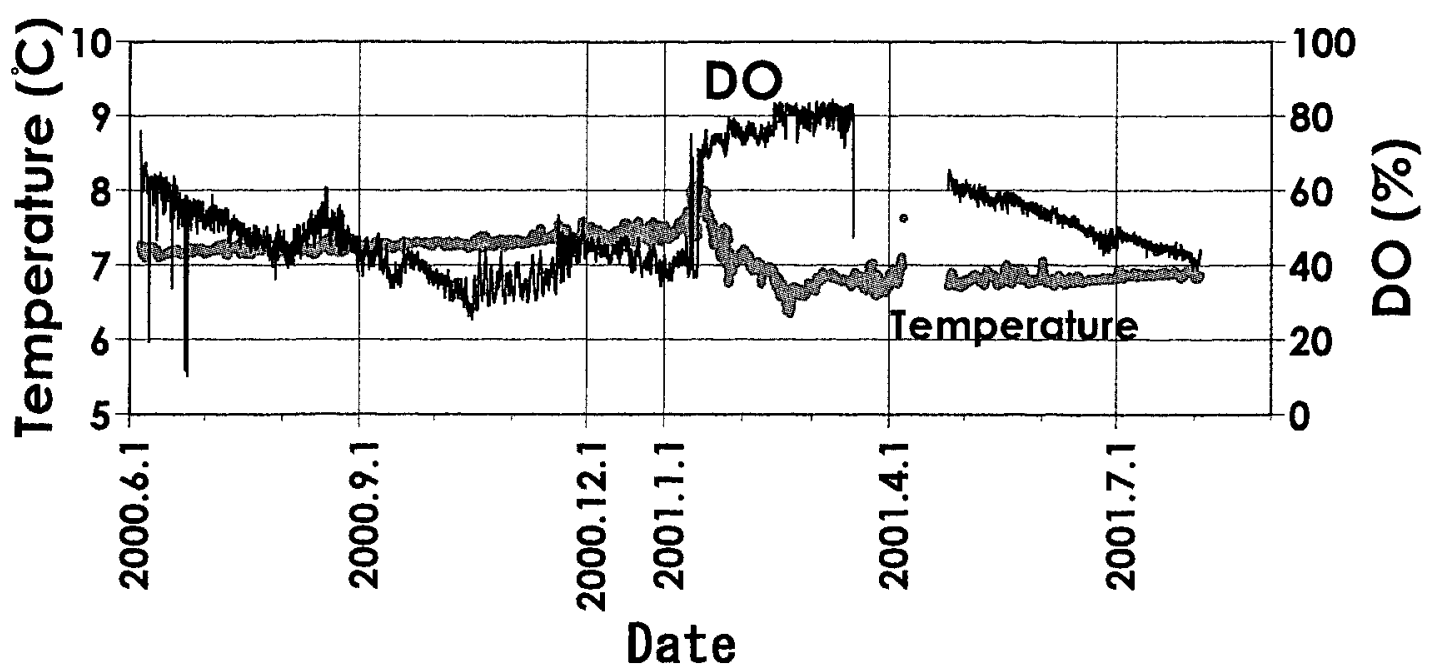

Fig. 2. Time variation of dissolved oxygen and temperature of deep water during the period from 5 June 2000 to 3 August 2001.

図 2. 底層における溶存酸素濃度と水温の時系列(2000年 5 月 5 日〜2001 年 8 月 3 日)。

Temperature ( $\mathrm{C}$ )

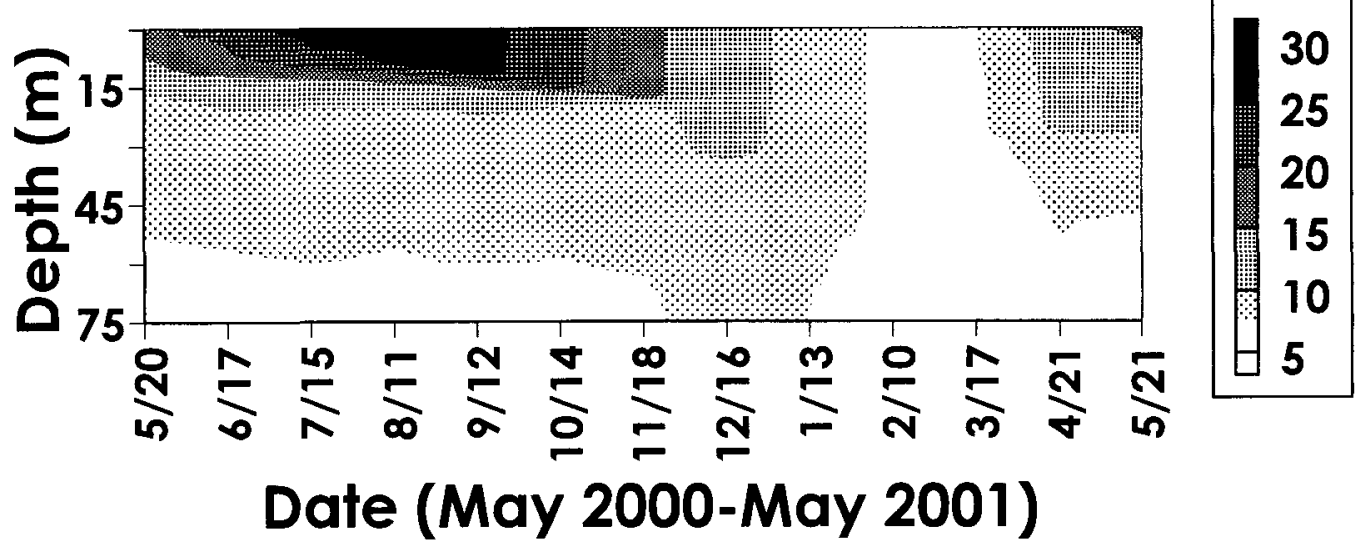

Fig. 3. Seasonal changes in temperature at the mooring site from May 2000 to May 2001. 図 3. 溶存酸素計の設置点における水温の季節変化(2000 年 5 月〜 2001 年 5 月).

1985)，水塊が大きく入れ替わった事によって溶存酸素 飽和度の值が大きくなったのかもしれない。

風の影響で底層に強い流れが生じる(奥村・遠藤， 1985)場合があり，強風によって表層水が撹找され，そ の影響が遅れて底層におよび，水塊が入れ替わる事に よって，溶存酸素飽和度が大きくなる場合があると思わ れる。

8月中旬以降から 10 月中旬にかけては, 9 月に少し大 きくなることはあるが，ほぼ単調に減少していき，10 月 15 日の約 $25 \%$ が最低の溶存酸素飽和度であり, 無酸 素状態にはならなかった。それ以降は12月初めにかけ
て，大きな変動を繰り返しながらも，増加の傾向にある。 しかし，12月初めから全層循環の起こる1月中旬にか けて, 再び溶存酸素飽和度は減少していく。

增加の原因についてはよく分からないが，気温の低下 によって冷却された表層水が沈降したことが，原因の一 つとして考えられる。

水温だけを取り出し拡大した図を Fig.4に示す。水温 は微少な変動を繰り返しながら上昇傾向にあり，2000 年 6 月から 12 月の半年間に打ける温度上昇は約 $0.25^{\circ} \mathrm{C}$ である。水温の微少な变動幅は 11 月初旬までは約 $0.1{ }^{\circ} \mathrm{C}$ であるが，それ以降は約 $0.2^{\circ} \mathrm{C}$ になっていて，これは成 


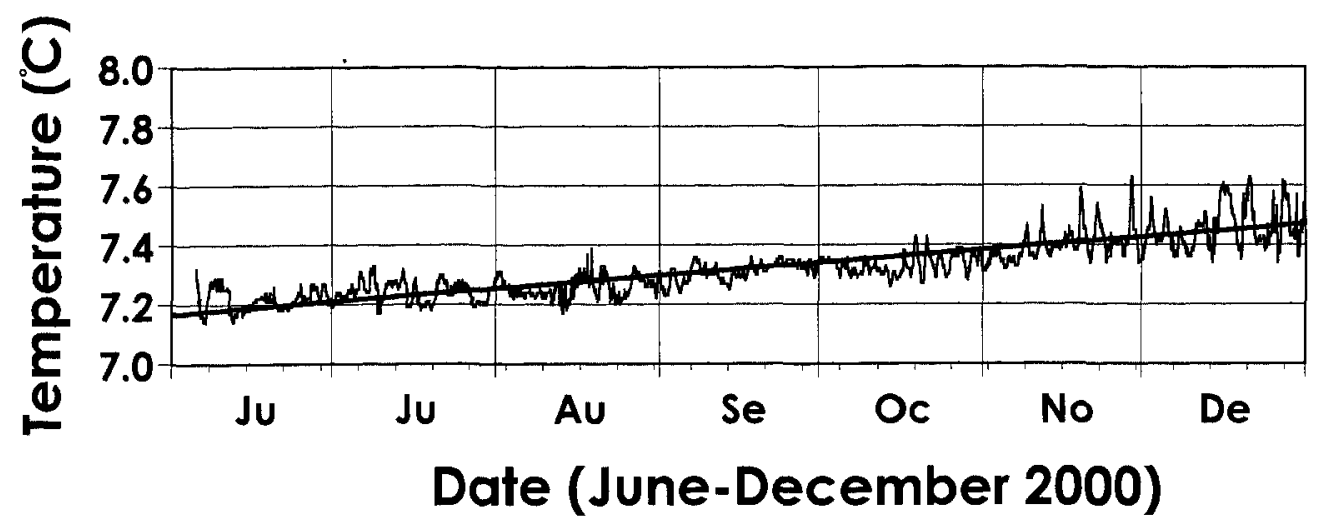

Fig. 4. Expanded figure of temperature time series in Fig. 2 from June to December 2000. 図 4. 図 2 の水温の時系列の拡大図 (2000 年 6 月 $~ 12$ 月).

勫が弱まり，冷却された表層水が沈降してきたことを示

しているのではないかと思われる。

2001 年 1 月 14 日に全層の湖水が完全に混合したこと によって, 急激に溶存酸素飽和度が増加し, 約 $80 \%$ ま で回復している。この状態は 3 月中旬まで続き, 成層が 始まると共に減少していくものと思われるが，センサー の不調と検定のため 4 月末まで欠測である。4月末以降 はまた 1 日当たり約 $0.2 \%$ の割合で単調に減少してい く。

底層の温度は，6月から全層循環が起こる1月中旬ま での間は少しずつ連続的に上昇を続け，全層循環時に急 に上昇し，その後，約 35 日間で約 $1.5^{\circ} \mathrm{C}$ 低下し， $6.5^{\circ} \mathrm{C}$ 以下になっている。最近では底層の温度も上昇傾向にあ り(遠藤ら，1999)，約 $8^{\circ} \mathrm{C}$ まで上昇することがあったが, 2001 年の冬は寒冷であった事により、低くなっている。

成層期に㧍ける溶存酸素飽和度の回復のメカニズムに ついては不明な点が多く観測を続け, さらにデー夕を蓄 積する必要がある。

\section{謝 辞}

常に観測にご協力いただいている(有)レークリサーチの 大村 仁社長と, 測器の設置・回収に協力された大阪電 気通信大学と滋賀大学の学生諸君に感謝します。

\section{参考文献}

遠藤修一・山下修平・川上委子”・奥村康昭 (1999); 琵琶 湖における近年の水温上昇について．陸水学雑誌，60: 223-228.

遠藤修一・田中義人 · 眞壁奈津子 ・川鴄宗継 - 奥村康昭 (2001): びわ湖に流入する河川水の分散. 日本陸水学 会第 66 回大会講演要旨集，107.

川嶋宗継・原博一・板坂修·堀太郎 - 高松武次郎 - 小山 睦夫 (1983): 琵琶湖に打ける水質変動 I.マンガン, 鉄, 栄美塩類の底泥加の再溶出と酸化還元サイクル。 滋賀大学教育学部紀要 自然科学, 33: 67-101.

熊谷道夫 (1993): 琵琶湖湖底からのメッセージ。琵琶湖 研究所ニュース「オウミア」，44:1-2.

熊谷道夫・石川加奈子・焦春萌 (2001): 琵琶湖に扔ける 環流と生態系．知ってますかこの湖を一びわ湖を語る 50 章一, 琵琶湖百科編集委員会 $($ 編 $): 43-48$. サンライ ズ出版, 滋賀.

中賢治 (1973): びわ湖深層の全循環期前の溶存酸素量の 永年変化. 陸水学雑誌, 34:41-43.

奥村康昭・遠藤修一(1985):びわ湖における連続測流 （ I ）－測流の方法と流況の概要一。陸水学雑誌， 46: 135-142.

西條八束·三田村緒佐武 (1995): 新編湖沼調査法。講談 社サイエンティフィク，東京。

津田松苗・森下郁子 (1975): 琵琶湖にDO 4\%のところ がある. 陸水学雑誌, 36: 31-32.

前田広人 - 熊谷道夫 · 大西行雄 - 来田秀雄 - 河合章 (1987): 琵琶湖南湖窪地の底層水における無酸素下に 伴う水質と底質の変化: 琵琶湖水の動態に関する実験 的研究総合報告書 (II): 99-105. 琵琶湖研究所, 大津. 